\title{
Evaluation Effects of Different Planting Systems on Water Use Efficiency, Relative Water Content and some Plant Growth Parameters in Onion (Allium cepa L.)
}

\author{
Mousa IZADKHAH ${ }^{11}$, Mehdi TAJBAKHSH' ${ }^{2}$, Mohamad Reza \\ ZARDOSHTY²), Abdollah HASANZADEH GORATTEPH ${ }^{3)}$ \\ 1) Urmia University, Faculty of Agriculture Science, 47402-1027 Bloomington, Iran; ms.izadkhah@gmail.com \\ 2) Urmia University, College of Agriculture,West Azerbaijan, Iran; mahditajbakbsh@yahoo.com \\ 3) Agricultural and Natural Resources Research Institute, West Azerbaijan, Urmia, Iran; ahassanzadeh_g@yahoo.com
}

\begin{abstract}
To evaluate the effect of different sowing methods on water use efficiency, relative water content and some vegetative growth parameters of onion a study was carried out in the Agriculturalr research Center of East Azarbayjan in 2007-2008 cropping season. The experiment was a factorial by using the randomized complete block design with 4 treaments and 4 replications. The first factor was consistting of two sowing methods, dirct sowing (DS) and the transplanting method (TM), the second factor was including two onion cultivars 'Azarshahr' (red hull and later maturing) and 'Gooli-Ghesseh Zanjan' (bright-red, early maturing). Analysis of variance for the measured traits indicated that except for the relative water content (RWC), other traits were significant influenced by the sowing methods. TM had higher values of water use efficiency (WUE), bulbing ratio (BR), aerial leaves length (ALL), leaf area (LA), leaf area index (LAI), leaves dry weight (LDW), leaves fresh weight (LFW) and leaves saturation weight (LSW) than the DS methods. Maximum WUE $\left(6.07 \mathrm{~kg} \mathrm{~m}^{3}\right)$ and minimum WU $\left(9381 \mathrm{~m}^{3} \mathrm{ha}^{-1}\right)$ were obtained in TM. However, the lowest WUE $\left(4.19 \mathrm{~kg} \mathrm{~m}^{3}\right)$ and the highest WU $\left(115921 \mathrm{~m}^{3} \mathrm{ha}^{-1}\right)$ was obtained with DS. In other words, in TM water economizing was $1.5 \mathrm{tim}$, amount of yield was increased up 15\% (in comparison with DS). Also among the cultivars except for the RWC, WUE and BR other traits were significantly. The sowing method x cultivar interaction were not significant. For the studied traits, TM and red 'Azarshahr' cv. were better than the DS and 'GooliGhesseh Zanjan', thus thy were identified the best treatments for experiment therefore it is recommended for the places with the same environmental conditions of this experiment.
\end{abstract}

Keywords: onion, water use efficiency, relative water content, transplanting method (TM), direct sowing (DS)

\section{Introduction}

Onion (Allium cepa L.) is a bulbous crop widely cultivated in almost every country of the world. It is one of the important condiments being widely used either in green form or as mature bulb or both used as salad and in preparations of immeasurable number of dishes, like soups, sauces and for seasoning of foods. The smaller bulbs are pickled in vinegar. Onion bulb is rich in phosphorous, calcium, and carbohydrates, along with this a medium onion (50 g in weight) contains 60 calories, 1 gram proteins, 16 grams carbohydrate, no fat, 5 milligrams sodium, 200 milligrams potassium, dietary fiber 3 grams. In Iran, there has been a progressive increase in its cultivated area and production. In 2007-2008 a total area of 500 thousand hectares, with total production of 1600 thousand tones of onion bulbs were reported, resulting an average yield of 34.04 tones ha ${ }^{-1}$. Onions can be direct seeded in the field, trans-planted and grown from onion sets. TM has a ben- eficial effect on onion production in several reasons for using transplants: transplanted crops normally mature earlier than field drilled crops of the same cultivar, higher total, marketable and biological yield, harvest index and homogeneous bulbs than DS and also prevents a change in soil structure. The commercial production of large bulbs from transplants is the most prevalent in regions where the onion crop is grown during the winter and harvested in the spring. However, it is also practiced in regions where onions are grown as a summer crop-not only to give a longer growing season for late-maturing cultivars, but also to give early-maturing types an opportunity to make sufficient growth before long days and high temperatures force them to bulb. Finally, the yields from transplanted crops are usually higher than from directly sown crops. The transplanting method (TM) in more common than direct sowing (DS) in onion production and research in developed countries (Kvet et al., 1971; Hegde, 1978; Nagre et al., 1984; Iortsuun and Khan, 
1989; Farrage, 1989; Atter et al., 1991; Matsui et al., 1994). In trials with the onion cvs. Yellow Berrnuda and Granex the highest yields resulted from TM and the lowest from DS (Ramtohul and Splittstoesser, 1979).

Khokhar et al. (1990) obtained data on bulb maturity, bulb weight and yield either directly in the field or in the nursery followed by transplanting at 3 dates, for each method. The differences between methods and dates were highly significant TM gave batter results for bulb yield (5.2-31.4 t/ha) and bulb weight (80.5-441.4 g) than DS (6.4-26.8 t/ha and 20.8-177.8 g, respectively. Izadkhah et al., (2009) reported that TM produces a higher plant single yield, biological yield and harvest index than DS in Iran. Rao (1988) indicated that TM gave the highest leaf area (LA), dry matter (DM), leaf area index (LAI), crop growth rate(CGR) and net assimilation rate( NAR) than DS in the field.

In onion production areas of Iran, the farmers are not aware of the advantages of TM .They sow onion seeds as DS and then cover them with sand in order to facilitate germination, emergence of seeds and seedling establishment. This method is one of the most important causes of changes soil texture in onion production areas. In addition the bulbs have larger variation in diameter and weight. The present study was aimed at comparing the two sowing methods of DS and TM for Plant water relation and the vegetative growth parameters.

\section{Materials and methods}

Field experiment was carried out in the Agricultural research Center of East Azarbayjan in 2007-2008 cropping season. The experiment was laid out using Randomized Complete Block Design (RCBD) with factorial arrangements. The experiment consisted of 4 treatments and four replicates. The first factors were two sowing methods, Dirct sowing (DS) and the transplanting method(TM), while the second factor were two onion varieties 'Azarshahr' and 'Gooli-Ghesseh Zanjan' Tab. 1.

The total area of each plot was $8 \mathrm{~m}^{2}$ being divided into 10 rows with $4 \mathrm{~m}$ length and $2 \mathrm{~m}$ width. The spacing was $20 \mathrm{~cm}$ between rows and $10 \mathrm{~cm}$ between plants. For nursery raising, onion seeds were sown on 9th February, 2007 in raised bed. On 25 $5^{\text {th }}$ March 2008, the sets of the two cultivars were sown at a rate of $25 \mathrm{~kg} / \mathrm{ha}$ (with a final density of $5 \times 5 \mathrm{~cm}$ or 400 plants $/ \mathrm{m}^{2}$ ) in Ds and the seeds were then covered with sand at $62 \mathrm{~kg} / \mathrm{plot}$ in all DS plots, the seedling of the two cultivars were also transplanted at $20 \times 10 \mathrm{~cm}$ or 50 plants $/ \mathrm{m}^{2}$ on 30th Aprill 2008 for TM. The seedlings were transplanted in their respective plots at two leaves stage and had the characteristics shown in Tab. 2.

The physical and chemical characteristics of experiment soil such as $\mathrm{pH}, \mathrm{ECe}$, organic matter, NPK were calculated (17) and presented in Tab. 3. Fertilizers was applied at the rate of $(150: 50: 100) \mathrm{N}: \mathrm{P}_{2} \mathrm{O}_{5}: \mathrm{K}_{2} \mathrm{O} \mathrm{kg} \mathrm{ha}{ }^{-1}$. Di Ammonium phosphate and Sulphate of Potash, were applied to all treatments at the time of field preparation. Nitrogen fertilizer, in the form of urea, was applied as two equal doses, 45 and 90 days after seedlings transplanting of each plots. All other common farming practices for the onion were also performed.

Irrigation was scheduled based on cumulative pan evaporation (CPE) when reached to $37 \mathrm{~mm}$, registered from a computerized weather station.

A surface irrigation system was used to irrigate plants. Amount water consumption was recorded by volumetric counter in different treatments, during 7 day intervals. During the growing period and after harvesting, some plant growth measurements were taken to determine difference in plant water relation and vegetative growth as affected by different planting methods. In August and October 2008, 'Gooli-Ghesseh Zanjan' and 'Azarshahr' respectively the bulbs of each plot were harvested when they were fully matured.

Plant water relation measurements, including: relative water content (RWC), water use efficiency (WUE) and water used (WU) was conducted. Water use efficiency values were calculated with by dividing of the total bulb yield $\mathrm{kg}$ by $\mathrm{m}^{3}$ water consumed according to the following equation (Begg and Turner, 1976).

$$
\text { WUE }=\frac{\text { Total bulb yield }(\mathrm{kg} / \mathrm{ha})}{\text { Seasonal ET }\left(\mathrm{m}^{3} / \mathrm{ha}\right)}=\mathrm{kg} / \mathrm{ha}-\mathrm{m}^{3} \text { water }
$$

Tab. 1. Characteristics of onion cultivars used

\begin{tabular}{ccccccc}
\hline Cultivars quality & Origin & Bulb Shapes & Skin color & Flesh color & Growing period (Day) & Storage \\
\hline 'Azarshahr' & Iran & Globe & Red & White Purple & $188-190$ & High \\
'Gooli Ghesseh-Zanhan' & Iran & Flattened globe & Brown Red & White & $155-159$ & Medium \\
\hline
\end{tabular}

Tab. 2. Seedling characteristics (after 75 days)

\begin{tabular}{cccccccc}
\hline Characteristics & $\begin{array}{c}\text { Length of } \\
\text { Seedling }(\mathrm{cm})\end{array}$ & $\begin{array}{c}\text { Bulb diameter } \\
(\mathrm{mm})\end{array}$ & $\begin{array}{c}\text { Diameter neck } \\
(\mathrm{mm})\end{array}$ & $\begin{array}{c}\text { Length of roots } \\
(\mathrm{mm})\end{array}$ & $\begin{array}{c}\text { Number of } \\
\text { roots }\end{array}$ & $\begin{array}{c}\text { Number of } \\
\text { leaves }\end{array}$ \\
\hline Mean & 20 & 4.57 & 3.21 & 51.26 & 9.70 & $2-3$ \\
Standard error & 1.7 & 0.284 & 0.15 & 3.18 & 1.18 & - \\
\hline
\end{tabular}


90

Tab. 3. Physical and chemical characteristics of crop experimental soil

\begin{tabular}{ccc}
\hline Soil Characteristics & Unit & Value Texture \\
\hline Sand & $\%$ & 42 \\
Silt & $\%$ & 37 \\
Clay & $\%$ & 21 \\
Textural Class & Sandy loam pH & 7.9 \\
Ece & $\mathrm{dSm}^{-1}$ & 0.53 \\
Nitrogen & $\mathrm{glOog}^{-1}$ & 0.43 \\
Available Phosphorus & $\mathrm{mg} \mathrm{kg}^{-1}$ & 4.50 \\
\hline Potassium & $\mathrm{mg} \mathrm{kg}^{-1}$ & 218 \\
Organic Matter & $\mathrm{gl00g}^{-1}$ & 0.53 \\
\hline
\end{tabular}

Relative water content: to determine RWC, after a period of two weeks without irrigation before harvest treatments, five plants were randomly taken from each plot, immediately leaves fresh weight was weighed, then the leaf samples were chopped to small pieces and placed into a container with distilled water at darkness for a period of 4 hr to a measurement saturation weight leaves (SWL), then leaf samples were dried by paper towel and placed into a oven dried at $80^{\circ} \mathrm{C}$ for a period of $48 \mathrm{hr}$ and dry weight (DW) weighting by sensitive digital balance (with accuracy of $0.0001 \mathrm{G}$ ). The RWC measurement was carried out according to (Barr et al., 1962):

$$
\mathrm{RWC}=\frac{\mathrm{F}_{\mathrm{W}}-\mathrm{D}_{\mathrm{w}}}{\mathrm{S}_{\mathrm{W}}-\mathrm{D}_{\mathrm{W}}} \times 100
$$

Where: $\mathrm{RWC}=$ relative water content, $\mathrm{FW}=$ fresh weight leaves, DW = dry weight leaves, $S W=$ saturation weight leaves.

The measurements vegetative growth parameters were included: length of the aerial leaves (ALL), saturation/dry/ fresh weight leaves (LSW, LDW, LFW), leaf area $\left(\mathrm{cm}^{2}\right)$, leaf area index, harvesting date (HD), bulbing ratio(BR) and number of days bulbing.

The leaf area index (LAI) was calculated according to Winter and Ohlrorgge (1988) as follows:

$$
\text { LAI }=\frac{\text { Leaf area } / \text { plant }}{\text { Land area } / \text { plant }}
$$

Bulbing ratio was calculated by dividing bulb diameter by neck diameter. Leaf area was determined by the nondestructive method of Gamiely et al. (1991) using the following equation area $=-93.1+1.83 \mathrm{~L}+38.6 \mathrm{C} 25$, where ' $\mathrm{L}$ ' is total leaf length (in centimeters) and C25 is leaf circumference(in centimeters) at $25 \%$ total leaf length from the leaf base. This equation gave high predictability with coefficient of determination of 0.96 .

The data for the water use efficiency (WUE), relative water content (RWC), water used (WU), harvesting date (HD), bulbing ratio (BR), number of day bulbing, aerial leaves length (ALL), leaf area (LA), leaf area index (LAI), leaves dry weight (LDW), leaves fresh weight (LFW) and leaves saturation weight (LSW) were transformed according to procedures described by Steel and Torrie (1991) to improve normality. The data collected were subjected to statistical analysis of variance using the Statistic Analysis System (SAS) version 8.2. Treatment means that were significantly different were compared using Duncan's Multiple Range Test (DMRT) according to Gomez and Gomez (1984).

\section{Results and discussion}

\section{Plant water relation parameters}

The plant water relation traits such as water use efficiency (WUE), relative water content (RWC) and water used (WU) have been presented in Tab. 4. Results showed that, except for the relative water content, other traits such as water use efficiency, and water used were significantly influenced by the sowing methods. The interaction effect of sowing method and varieties showed a non significant on the plant water relation (Tab. 4). TM gave the highest water use efficiency (WUE) and lowest water used (WU) $\left(6.07 \mathrm{~kg} / \mathrm{m}^{3}, 9532 \mathrm{~m}^{3} / \mathrm{ha}^{-1}\right.$ respectively) whereas the lowest values water use efficiency (WUE) and highest water used (WU) were obtained from DS $\left(4.19 \mathrm{~kg} / \mathrm{m}^{3}, 11441 \mathrm{~m}^{3} /\right.$ $\mathrm{ha}^{-1}$ respectively) (Tab. 5). In other words, in TM water economizing was 1.5 tim, amount of yield was increased up $15 \%$ (in comparison with DS). These results were similar to those obtained by Leskovar et al., (2002). They found that transplants had higher water use efficiency than direct seeded plants (average of 6,307 vs. 4,400 lb/inch water applied+rain). Also the varieties showed except for the water used, other traits were non significant difference on the plant water relation traits. The hightest water used. were found in red 'Azarshahr' $\left(11592 \mathrm{~m}^{3} / \mathrm{ha}^{-1}\right)$ while the lowest were obtaind in 'Gooli-Ghesseh Zanjan'(9381 $\mathrm{m}^{3}$ / $\left.\mathrm{ha}^{-1}\right)$ (Tab. 5).

\section{Vegetative growth parameters}

\section{Harvesting date}

The Analysis of variance for harvesting date indicated a highly significant difference on it and influenced by the sowing methods and cultivars Tab. 4. The varieties and their interaction with sowing methods showed a non significant difference on harvesting date.

The mean harvesting date was 167 days after transplanting in TM. However, the harvesting date for the DS was longer than the TM (187 vs 167). There was decreased in harvesting date for TM (Tab. 5). These findings were harmony with those reported by Ramtohul and Splittstoesser (1979), Sabota and Downes(1975). Also, the highest harvesting date (188 day) were obtained from red 
Tab. 4. Analysis of variance effect of sowing methods and cultivars on water use efficiency, relative water content, water used, harvesting date, bulbing ratio and number of day bulbing

\begin{tabular}{cccccccc}
\hline Trait & df & WUE $\left(\mathrm{kg} / \mathrm{m}^{3}\right)$ & RWC $(\%)$ & WU $\left(\mathrm{m}^{3}\right)$ & HD(Day) & BR & No. of Bulbing (Day) \\
\hline Source of variation & & & & & & \\
Block & 3 & $0.2772 \mathrm{~ns}$ & $23.321 \mathrm{~ns}$ & $0.002 \mathrm{~ns}$ & $55.229 \mathrm{~ns}$ & $0.6796 \mathrm{~ns}$ & $15.500 \mathrm{~ns}$ \\
Sowing methods (SM) & 1 & $14.118^{* *}$ & $3.250 \mathrm{~ns}$ & $1457.2^{* *}$ & $1660.56^{* *}$ & $8.558^{*}$ & $164.25^{* *}$ \\
Cultivars (C) & 1 & $0.189 \mathrm{~ns}$ & $45.320 \mathrm{~ns}$ & $1954.84^{* *}$ & $218.562^{* *}$ & $0.567 \mathrm{~ns}$ & $3969^{* *}$ \\
SM $\times$ C & 1 & $0.0232 \mathrm{~ns}$ & $0.232 \mathrm{~ns}$ & $40.65 \mathrm{~ns}$ & $0.0012 \mathrm{~ns}$ & $30.25 \mathrm{~ns}$ & $5.062 \mathrm{~ns}$ \\
Error & 9 & 0.0150 & 0.236 & 23.123 & 26.395 & 0.8182 & 9.222 \\
cv & & 2.38 & 12.35 & 1.25 & 2.89 & 8.18 & 4.11 \\
\hline
\end{tabular}

WUE: Water Use Efficiency; RWC: Relative Water Content; WU: Water Used; HD: Harvesting Date; BR: Bulbing Ratio and No. of Bulbing: Number of day Bulbing ${ }^{*},{ }^{* *} \&$ ns: Significant at $\mathrm{p}<0.05, \mathrm{p}<0.001$, non-significant respectively

'Azarshahr', whereas lowest were found in 'Gooli-Ghesseh Zanjan'(165 day) could be due to varieties, Tab. 5.

\section{Bulbing ratio and number of day bulbing}

The bulbing ratio (BR) and number of day bulbing were significantly influenced by the sowing methods, but the bettwen two cultivars bulbing ratio did not differ in these
5). This agree with the reports of other researchers (Wien, 1999; Ramtohul and Splittstoesser, 1979). The highest mean number of day bulbing ( 89 day) was found on red 'Azarshahr' and lowest (58 day) was found on 'GooliGhesseh Zanjan' which could be due to varieties and day length, field situation etc. (Tab. 5).

In a vertical column values having same letter(s) do not different significantly $(p \leq 0.05)$ from each other, accord-

Tab. 5. Mean comparison effect of sowing methods and cultivars on water use efficiency, relative water content, water used, harvesting date, bulbing ratio and number of day bulbing

\begin{tabular}{ccccccc}
\hline $\begin{array}{c}\text { Trait } \\
\text { Factors }\end{array}$ & $\begin{array}{c}\text { WUE } \\
\left(\mathrm{kg} / \mathrm{m}^{3}\right)\end{array}$ & $\begin{array}{c}\text { RWC } \\
(\%)\end{array}$ & $\begin{array}{c}\text { WU } \\
\left(\mathrm{m}^{3}\right)\end{array}$ & $\begin{array}{c}\text { HD } \\
(\text { Day })\end{array}$ & BR & $\begin{array}{c}\text { No. of Bulbing } \\
\text { (Day) Sowing methods }\end{array}$ \\
\hline DS & $4.19 \mathrm{~b}$ & $91 \mathrm{a}$ & $11441 \mathrm{a}$ & $188 \mathrm{a}$ & $9.52 \mathrm{~b}$ & $84 \mathrm{a}$ \\
TM & $6.07 \mathrm{a}$ & $90 \mathrm{a}$ & $9532 \mathrm{~b}$ & $167 \mathrm{~b}$ & $10.99 \mathrm{a}$ & $64 \mathrm{~b}$ \\
'Azarshahr' & $5.03 \mathrm{a}$ & $89 \mathrm{a}$ & $11592 \mathrm{a}$ & $189 \mathrm{a}$ & $1045 \mathrm{a}$ & $89 \mathrm{a}$ \\
\hline 'Gooli Ghesseh-Zanjan' & $5.07 \mathrm{a}$ & $87 \mathrm{a}$ & $9381 \mathrm{~b}$ & $165 \mathrm{~b}$ & $10.07 \mathrm{a}$ & $58 \mathrm{~b}$ \\
\hline
\end{tabular}

WUE: Water Use Efficiency; RWC: Relative Water Content; WU: Water Used; HD: Harvesting Date; BR: Bulbing Ratio and No.of Bulbing: Number of day Bulbing.

respects (Tab. 4). Significant interaction sowing method $\times$ cultivar were not observed on the general responses of the studied this characters (Tab. 4). The maximum bulbing ratio and the minimum number of day bulbing were found in TM (10.99 and 64 day respectively) whereas the minimum bulbing ratio and maximum number of day bulbing were obtaind in DS (9.52 and 83 day respectively (Tab. ing to Duncan`s Multiple Range Test (DRMT).

\section{Aerial leaves length, leaf area, leaf area index}

The aerial leaves length (ALL), leaf area (LA), leaf area index (LAI) was measured at the maturity stage and average was computed. The analysis of variance showed there

Tab. 6. Analysis of variance effect of sowing methods and cultivars on length of the aerial leaves, leaf area, leaf area index, saturation/dry/fresh weight leaves

\begin{tabular}{cccccccc}
\hline $\begin{array}{c}\text { Trait } \\
\text { Source of variation }\end{array}$ & df & $\begin{array}{c}\text { ALL } \\
\mathrm{cm}^{2} / \mathrm{plant}\end{array}$ & $\begin{array}{c}\text { LA } \\
\mathrm{cm}^{2} / \mathrm{plant}\end{array}$ & LAI & $\begin{array}{c}\text { LDW } \\
\text { (gr) }\end{array}$ & $\begin{array}{c}\text { LFW } \\
(\mathrm{gr})\end{array}$ & $\begin{array}{c}\text { LSW } \\
(\mathrm{gr})\end{array}$ \\
\hline Block & 3 & $1.343 \mathrm{~ns}$ & $21.932 \mathrm{~ns}$ & $12.56 \mathrm{~ns}$ & $1.254 \mathrm{~ns}$ & $153.335 \mathrm{~ns}$ & $142.1 \mathrm{~ns}$ \\
Sowing methods(SM) & 1 & $123.552^{* *}$ & $476.255^{* *}$ & $359.123^{* *}$ & $408.342^{* *}$ & $256.221^{* *}$ & $149.12^{* *}$ \\
Cultivars(C) & 1 & $103.022^{* *}$ & $678.42^{* *}$ & $537.218^{* *}$ & $128.084^{* *}$ & $9775.33^{* *}$ & $548.33^{* *}$ \\
SM $\times$ C & 1 & $0.0202 \mathrm{~ns}$ & $0.687 \mathrm{~ns}$ & $12.032 \mathrm{~ns}$ & $59.02 \mathrm{~ns}$ & $32.26 \mathrm{~ns}$ & $0.258 \mathrm{~ns}$ \\
Error & 9 & 1.350 & 17.214 & 45.258 & 2.051 & 144.009 & 256.354 \\
cr & & 3.03 & 16.38 & 7.56 & 8.09 & 8.56 & 12.25 \\
\hline
\end{tabular}

ALL, LA, LAI, LDW, LFW \& LSW indicates: Aerial Leaves Length, Leaf Area, Leaf Area Index, Leaves Dry Weight, Leaves Fresh Weight, Leaves Saturation Weight. ${\mathrm{n} . \text {, }^{*} \text { and }}^{* *}$ : non- significant; and significant at $\mathrm{p}<0.05$ or $\mathrm{p}<0.001$ level of probability using DMRT, respectively. 
Tab. 7. Mean comparison effects of sowing methods and cultivars on length of the aerial leaves, leaf area, leaf area index, saturation/dry/fresh weight leaves.

\begin{tabular}{ccccccc}
\hline Trait Factors & $\begin{array}{c}\text { ALL } \\
\mathrm{cm}^{2} / \text { plant }\end{array}$ & LA cm ${ }^{2} /$ plant & LAI & $\begin{array}{c}\text { LDW } \\
(\mathrm{gr})\end{array}$ & $\begin{array}{c}\text { LFW } \\
(\mathrm{gr})\end{array}$ & $\begin{array}{c}\text { LSW }(\mathrm{gr}) \\
\text { Sowing methods }\end{array}$ \\
\hline DS & $37.47 \mathrm{~b}$ & $1117 \mathrm{~b}$ & $5 \mathrm{~b}$ & $3.58 \mathrm{~b}$ & $35.94 \mathrm{~b}$ & $39.53 \mathrm{~b}$ \\
TM & $41.23 \mathrm{a}$ & $1773 \mathrm{a}$ & $8 \mathrm{a}$ & $5.33 \mathrm{a}$ & $57.39 \mathrm{a}$ & $63.13 \mathrm{a}$ \\
'Ayarshahr' & $40.89 \mathrm{a}$ & $1472.66 \mathrm{a}$ & $7 \mathrm{a}$ & $6.94 \mathrm{a}$ & $63.27 \mathrm{a}$ & $69.60 \mathrm{a}$ \\
\hline 'Gooli Ghesseh-Zanjan' & $35.81 \mathrm{~b}$ & $1377 \mathrm{~b}$ & $6 \mathrm{~b}$ & $5.79 \mathrm{~b}$ & $52.94 \mathrm{~b}$ & $58.23 \mathrm{~b}$ \\
\hline
\end{tabular}

ALL, LA, LAI, LDW, LFW and LSW indicates: Aerial Leaves Length, Leaf Area , Leaf Area Index, Leaves Dry Weight, Leaves Fresh Weight, Leaves Saturation Weight. Means within the same column followed by the same letter $(s)$ are not significantly different ( $\mathrm{p} \leq 0.05$ from each other, according to Duncan ` $\mathrm{sultiple} \mathrm{Range}$ Test (DRMT).

were significant difference between sowing methods and two cultivars on the ALL, LA and LAI (Tab. 6). The highest aerial leaves length, leaf area and leaf area index (41.23 $\mathrm{cm}, 1773 \mathrm{~cm}^{2} /$ plant, 8 respectively) was observed in TM.

Where as the lowest was obtained in DS $(34.47 \mathrm{~cm}$, $1117 \mathrm{~cm}^{2} /$ plant and 5 respectively) Tab. 7. Similar results are observed by other investigators (RAO, 1988; Farrage, 1989; Iortsuun and Khan, 1989). Their interaction with varieties and sowing methods showed a non-significant difference on mentioned traits. There were significant differences between two cultivars on ALL, LA and LAI (Tab. $6)$. The highest aerial leaves length, leaf area and leaf area index $\left(40.89 \mathrm{~cm}, 1472.66 \mathrm{~cm}^{2} /\right.$ plant, 7 respectively) was observed in red 'Azarshahr'. Where as the lowest was recorded in 'Gooli-Ghesseh Zanjan' $\left(35.81 \mathrm{~cm}, 13377 \mathrm{~cm}^{2} /\right.$ plant and 6 respectively, Tab. 7).

\section{Leaves dry weight, leaves fresh weight and leaves saturation weight}

Analysis of variance for leaves dry weight (LDW), leaves fresh weight (LFW) and leaves saturation weight (LSW) are shown in (Tab. 5). The sowing methods were difference significantly on the LDW, LFW and LSW traits. The average leaves dry weight, leaves fresh weight and leaves saturation weight increased form $3.58(\mathrm{~g})$, $35.94(\mathrm{~g})$ and $39.53(\mathrm{~g})$ in DS respectively, to $5.33(\mathrm{~g})$, 57.39 (g) and $63.13(\mathrm{~g})$ in TM respectively (Tab. 5). Similar results were reported by Iortsuun and Khan,1989. They indicated that TM gave better results for LDW, LFW and LSW than DS (Tab. 5).

There were significant differences between two cultivars for LDW, LFW and LSW traits (Tab. 5). Leaves dry weight, leaves fresh weight and leaves saturation weight, greater in red 'Azarshahr' (6.94 g, $63.27 \mathrm{~g}$ and $69.60 \mathrm{~g}$ respectively) than in 'Gooli-Ghesseh Zanjan' ( $5.79 \mathrm{~g}, 52.94$ $\mathrm{g}$ and $58.23 \mathrm{~g}$ respectively). Sowing method $\times$ cultivar interactions were not significant for this treats (Tab. 5).

Based on the above results transplanting method (TM) could be an effective method of producing onions without a change in soil texture. Furthermore due to TM gave the higher water use efficiency (WUE) and lower of amount water used (WU) than DS. In other words, in TM water economizing was 1.5 tim, which can be utilize an other crops, and also amount of yield was increased up 15\% (in comparison with DS). Therefore TM is recommended for regions with shortage of water is a limiting factor for agricultural productivity like arid and semi-arid. Thus recommended for the places with the same environmental conditions of this experiment.

\section{References}

Atter, S., B. N. Korla and A. Singh (1991). Effect of transplanting dates and varieties on number of leaves and yield in onion (Allium cepa L.). Vegetable Science. 18(1):24-28.

Baloch, A. F., M. A. Baloch, G. Ansari and A. H. Qayyum (1991). Effect of FYM on the yield of onion crop. Sarhad J. Agric. 4(4):34-53.

Barr, H. D. and P. E. Weatherley (1962). A reexamination of the relative turgidity technique for estimating water deficit in leaves. Aust. J. Biol. Sci. 15:413-428.

Begg, J. E. and N. C. Turner (1976). Crop water deficits. Adv. Agron. 28:161-217.

Duncan, D. B. (1955). Multiple range and multiple $F$ test. Biometrics. 11:1-42.

Farrage, M. M. (1989). Effect of inter and intra row spacing on growth, yield and bulb quality of onion cv. Giza 6. Assuit Journal of Agriculture Science. 10(2):187-104.

Gamiely, S., W. M. Randle, W. A. Milks and D. A. Smittle (1991). A rapid and nondestructive methodfor estimating leaf area of onions. HortScience. 26:206.

Gomez, K. A. and A. A. Gomez (1984). Statistical procedures for Agricultural Research John Wiley and Sons. Inc., New York.

Hegde, D. M. (1978). Growth analysis of onion (Allium cepa L.) in relation to irrigation and nitrogen fertilization. J. Agron. Crop Sci. 157: 227-234.

Iortsuun, D. N. and A. A. Khan (1989). The pattern of dry mutter distribution during development in onion J. Agron. Crop Sci 162:127-134.

Izadkhah, M., M. Tajbakhsh, M. R. Zardoshti, A. Hasnzade, F. Taheri, M. Saber-Rezaie, F. Feghnabil and S. Parvizi (2009). Invsttigation the influence of planting methods on bulb and 
biologic yield, harvest index and some morphological triats in onion (Allium cepa L.). Online International J. Agron. and Bio. (OIJAB) 2(4):189-193.

Kvet, J., J. P. Ondok, J. Necas and P. G. Jarvis (1971). Methods of growth analysis. Plant Photosynthetic production. N.V Publisheres.

Leskovar, D. I., K. Kolenda, K. S. Yoo and L. M. Pike (2002). Containerized Onion Transplants: I. A Strategy to Enhance Yield and Size.Texas A and M Agricultural Research and Extension Center at Uvalde.

Matsui, S. M., H. Shirai and Ykamur (1994). Growth analysis of onion (Allium cepa L.) plants treated with (s)-(+) abscisic acid. Res. Bull. Faculty of Agric. Gifu Univ. No. 59-27-62.

Nagre, P. K., L. V. Kulwal and P. B. Kale (1985). Effect of different days of transplanting and spacing on growth and yield of onion cv. Local white. PKV Research Journal 11(2):151-155.

Nayerabi, S. A. F. and A. H. M. Ahmed (2001). The Commercial Vegetable of Pakistan Tropical Sci. 41(2):95-99.

Page, A. L., R. H. Miller and D. R. Keeny (1982). Methods of soil analysis. Part@II. Chemical and Microbiological properties 2nd ed. Amer. Soc Agron. Inc. Soil Sci. Sco.
Amer. Inc. Madison, Wisconsin, USA.

93

Ramtohul, M. and W. E. Splittstoessor (1979). Day length determines bulb size and time of maturity in onion. Illinois Research. 21:2-14.

RAO, K. S. (1988). Physiological analysis of growth and yield in onion (Allium cepa L.). Indian J. Agric. Sci. 58(6):489-491.

Sabota, C. and D. Downes (1975). Influence of spacing and transplanting size of maturity in onions (Allium cepa L.) grown in West Texas.

Steel, R. G. D. and J. H. Torrie (1991). Principles and Procedures of Statistics a Biometrical Approach. McGraw-Hill Book Company. New York.

Whitesid, W., F. Vandemark and W. E. Splittstoessor (1975). Seedling date and rate and supplement light effects on onion growth. J. Amer. Soc. Hort. Sci. 100:37-39.

Wien, K. C. (1999). The physiology of vegetable crops. CABI Press. New York. p.67.

Winter, S. R. and A. J. Ohlrorgge (1988). Leaf angle, leaf area and corn (Zea mays L.) yield. Agron. J. 65:395-402. 